\title{
Reflections
}

\section{Taqlid and the Stagnation of the Muslim Mind}

\author{
Țāhà J. al Alwānì
}

\section{The Origins and Beginnings of Taqlid}

Allah Most High chose the Muslims to be the ummah of mission (risälah), of exemplary good (khayrīyah), of the golden mean (wasatìyah), and of witnessing to humanity (shahädah). Along with these responsibilities came the capacity for renewal, for ijtihad, and for correctly interpreting the Shariah. As a result, there is a certain inseparable mutuality between the ummah's roles as a median community cum civilizational witness for humanity and its other role as a moral and ethical exemplar, and between its capability for ijtihad and effecting reform. In order to facilitate these roles, Allah endowed the Qur'an and the Sunnah with the necessary flexibility in every aspect of Islam: its belief system, its methodology, its Shariah, and its organization.

Thus it was only natural for the early generations of Muslims, both on an individual and a community level, to offer a unique picture to the world: the complete liberation of the human mind from all forms of mental slavery and idolatry. Further protection against falling from this exalted position was the provision made for avoiding mistakes, deviations, and misinterpretations: only those statements which could be proven by acceptable evidence or supported by valid testimony were to be believed. A look at the ijtihad exercised by the Sahäbah, whether they were learned qurrä' or common people, will suffice to illustrate the amazing transformation which Islam was able to achieve.

Why do we not see this situation today? What has happened to the penetrating and enlightened mind inspired by Islam, the one which freed our ancestors from their idols and the obstacles blocking their progress? How did such a mind return to its former prison and fetters, robbed of any chance to renew and reform the ummah through ijtihad? In a word, the answer is

Tāhä J. al 'Alwānī is a member of the Fiqh Academy of the Organization of the Islamic Conference, chairman of the Fiqh Council of North America, and president of the International Institute of Islamic Thought in Herndon, Virginia. 
taqlid, an illness which entered the Muslim mind and then fed on it until it returned to its prison.

This paper is a study of taqlid, one designed to reveal why it has overtaken the ummah.

\section{Taqlid and the Ummah's Crisis}

Muslims and non-Muslims alike are amazed that one of history's most advanced civilizations could fall into such a state of overwhelming wretchedness, ignorance, backwardness, and overall decline. Why are there so many crises in the ummah's thought? Why, when it possesses sufficient natural, human, spiritual, and civilizational resources, does the ummah's vision remain cloudy and its list of priorities confused? The answer(s) to such questions has not yet been found, despite the innumerable studies which have dealt with the overall problem by means of different methodologies and despite the fact that their results and conclusions concerning the causes have been identified, published, and analyzed.

But the amazement and frustrations remain. A civilization which has placed such emphasis upon literacy and knowledge remains largely illiterate. An ummah which received such clear divine guidance remains mired in a morass of misunderstanding, misinterpretation, and outright confusion.

Other questions waiting to be answered are: How did the ummah of unity and tawhid become divided into so many sects and subsects? Why does the ummah, blessed with all of the means and resources for economic prosperity, continue to suffer from abject poverty? Why does the ummah, which was given the means of dominance and invincibility, remain subjected to continuing political and military humiliation? Why does the thought of its people, to whom all the sources of guidance were revealed, remain awash in fallacy and delusion?

However, our situation is even worse than that outlined above, for we see parts of our ummah trying to defend these aberrations by presenting them as wholesome, ascribing them to others, trying to find scapegoats, or even attempting to downplay their importance by explaining that such things are natural and common.

\section{Taqlid: A Natural (Original) Condition or a Deviation?}

Allah has blessed this ummah with an 'aqìdah, a Shari'ah, and a minhäj. Aqidah is what gives a Muslim a clear perception of life and the universe based on the principle of pure tawhìd in harmony with fitrah (the pattern 
on which Allah has made humanity ${ }^{1}$ ), in balance with all that exists and in explanation of all the elements that make up civilization: istikhla $\bar{f},^{2}$

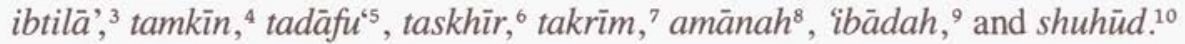

The Shariah is a blessing because of its universality, its comprehensiveness, its perfection, its effectiveness in preserving all the necessities of existence, and its provision of what is needed to build a civilization and its identity. The Shariah, moreover, comprehends all elements which give Islamic life its particular color and taste and also contributes to the achievement of Islam's higher objectives. As such, the ummah will only achieve success and felicity in this life and in the hereafter, and the Muslims will only be able to successfully fulfill their role as Allah's vicegerent, if the Shari'ah's objectives, purposes, and principles are clearly understood and appreciated.

The minhäj of Islam is a blessing, for the Prophet said: "It is the shining path whose night is as clear as its day." Thus one who uses his/her reason and senses cannot go astray, for following them leads an individual to felicity, a society to the common good, and the ummah to its goals of wasatiyah and shahädah.

Islam's aqīdah, Shari'ah, and minhāj can only be applied by a mind illuminated with sure knowledge of and faith in Allah, able to understand His purposes and principles, conscious of Islam's premises so that they may be connected intelligently, and capable of achieving the highest degree of discernment. This is why Islam is so determined to free the human mind from its previous and present fetters. It is even stated in the Qur'an that if this is not first accomplished, His ummah will be unable to perform ijtihad,

${ }^{1}$ See Qur'an 30:30.

${ }^{2}$ Istikhläf is Allah's appointment of humanity as His khalifah (vicegerent) on earth. See Qur'an 2:30; 10:14; 27:26; 35:39.

${ }^{3} I b t i l a ̈$ ' means trial by affliction or through abundance. See Qur'an 3:186; 21:35; 89:15-16.

${ }^{4}$ Tamkin, or Allah's aid in establishing people in the world, be it politically, financially, professionally, or otherwise, carries with it the responsibility of the individual and his/her society to reciprocate through establishing prayer and good deeds. See Qur'an 22:41; 6:6; 7:10.

${ }^{5} \mathrm{Daf}$ ' and Tadäfu' have the meaning of checking and balancing one group of people, or an individual, checking another. See Qur'an 22:40; 2:251.

${ }^{6}$ Taskhir is Allah's subjection of nature and its laws to humanity for its benefit. For this favor, it is essential that humanity shows its gratitude (shukr). See Qur'an 22:36-37; 14:32; $16: 12,14 ; 22: 65 ; 35: 13$.

${ }^{7}$ Takrim is the word for the honor and favor bestowed on humanity by Allah. See Qur'an 17:70.

${ }^{8}$ Amänah is the trust which Allah gave to humanity; the innate ability to choose between good and evil. It is this trust which sets humanity at the pinnacle of Allah's creation. See Qur'an 33:72.

${ }^{9}$ The purpose of humanity's creation is ibädah. See Qur'an 51:56.

${ }^{10}$ Shuhüd is the concept of civilizational witnessing which Allah has made obligatory upon His ummah. See Qur'an 2:143; 3:140; 4:135, 5:8; 22:78. 
to carry out reform, to give guidance, or to follow in the prophets' footsteps: "Those were the ones who received Allah's guidance; so emulate the guidance they received" (6:90). Thus we can say that the present state of the Muslim mind is unnatural, for it has accepted without proof many concepts and practices which have led to the arrest and petrification of reason.

For the ummah, taqlid represents a blameworthy innovation (bid'ah) as well as a deviation from the straight path (dalälah). No researcher or scholar has ever found a valid text from either the Qur'an or the hadith, or even an argument based on pure reason, to support Islam's approval of taqlid, for the very idea is alien to Islam's view of humanity. The teachings of Islam clearly state that all assertions must be supported by either verifiable evidence or proof. If these elements are absent the statement must be rejected. This applies to all statements (a fact has to be verifiable), a claim (it also has to be verifiable), a ruling (it must have either valid testimony or evidence), or a command or a prohibition (they must have an issuing authority based either in revelation or existence and thus subject to empirical validity). If such conditions cannot be met the assertion is to be rejected. These, then, are the basic landmarks in the methodology of the Muslim mind.

\section{Taqlid: For Muslims or Non-Muslims?}

A Muslim, or one who has been liberated from all shackles and fetters by the grace of Allah, has a free mind and a clear conscience. Thus, he/she will accept only the truth - that which is supported by proper evidence. NonMuslims, those who have remained chained to and enslaved by their continued idolatry (shirk), have been and remain easy preys for any sort of falsity.

Of them, Allah has stated:

When it is said to them: "Follow what Allah has revealed!" They say: "On the contrary, we shall follow the ways of our fathers." What? Even though their fathers were devoid of wisdom and guidance? (Qur'an 2:170).

and:

In the same way, We never sent a warner before you to any people except that the wealthy ones among them said: "We found our fathers following a certain religion; and certainly we shall follow in their footsteps" (Qur'an 43:23).

And they said: 
O Lord! We obeyed our chiefs and our great ones and they led us astray from the right path (Qur'an 33:67).

Sometimes, an overbearing person will deceive others so as to influence them and, in the name of religion, gain control of their thinking. This is usually done by claiming for himself/herself one of the uniquely divine attributes, like the attribute of legislation. Citing those who follow such people as deluded, Allah has said: "They take their priests and their anchorites to be their lords in derogation of Allah" (Qur'an 9:31).

Commenting on this verse, Hudhayfah related a hadith in which 'Adī ibn Hātịm (a convert from Christianity) said to the Prophet:

\begin{abstract}
"But we didn’t actually worship them, O Rasūl Allāh!” The Prophet replied: "But did they not make what was harām for you halāl and what was halāl for you haräm? And did you not follow what they told you?" 'Adĩ replied: "Yes," to which the Prophet said: "This is how you worshipped them."11
\end{abstract}

Such evidence has caused Muslim scholars to agree that taqlid is wrong and must be avoided. Counterarguments that these verses were directed towards the non-Muslims' and not the Muslims' use of taqlid are rejected on the grounds that any similarity between a muqallid in matters of kufr and a muqallid in anything else is not kufr, but only following the customs of deceased Muslims which may or may not have been in conformity with the Shari'ah.

In addition, Muslim scholars are generally agreed on the blameworthiness of taqlid in general, even if they differ on its degree and various forms. Obviously, one who follows a disbeliever is not the same as one who follows a sinner. Likewise, one who follows an ignorant person on a question of daily life is not the same as one who follows an ignorant person on a matter of religion. Still, it is not fitting for a Muslim to be involved in any sort of taqlid, as Allah has explained to humanity what may protect and preserve it from this: "Allah will not mislead a people after He has guided them, in order to make clear to them what they are to avoid" (Qur'an 9:115).

A Muslim must never accept anything without proof or believe anything without evidence of its validity. Allah has emphasized this by linking a Muslim's legal competence with his/her ability to use reason. Thus, if he/she becomes unable to reason according to Islamic norms and values, his/her competence is invalidated.

Any supposition unsupported by sound evidence (zann) is subject to certain rules, for there are some matters in which it, in the absence of anything

${ }^{11}$ This hadith was related by several Qur'anic commentators. The original hadith, however, may be found in the collection of al Tirmidhi. 
better, is acceptable. Generally speaking, however, any supposition is to be rejected, for a Muslim is expected to actively seek out what is certain and not to rest until he/she is satisfied that the evidence is conclusive. Among the early Muslims this was a self-evident fact and none of them ever accepted, used, cited, or fell back on taqlid.

\section{Sources of Knowledge}

Allah has divided the various sources of knowledge into two basic categories: a) Revelation (Wahy), as He has said in the Qur'an: "He revealed to you the Book (the Qur'an) and hikmah (the Sunnah), and He taught you that which you did not know (4:113); "He taught Ādam the names of all things" (2:31); and "Recite in the name of your Lord Who created, created mankind from a blood clot! Recite, for Your Lord is the Most Noble, the One Who taught by means of the eternal pen (of revelation); Who taught mankind what it did not know" (96:1-5) and b) The Universe (al Kawn), for he has told us that: "Verily in the creation of the heavens and earth, in the alternation of night and day, in the ships that glide through the ocean with what benefits mankind, in the water Allah sends down from the sky to revive the earth after it was dead and to scatter throughout it every manner of beast, in the changing of the winds, in the clouds made subservient between the heavens and earth, are signs for a people who reason" (2:164).

Allah has even informed humanity how it can attain knowledge from these two sources: "Allah brought you forth from the wombs of your mothers when you knew nothing; and then He gave you hearing and sight and intelligence" (16:78); "It is not given to any human that Allah should speak to him/her except through revelation, or from behind a screen, or by sending a messenger who reveals, by His leave, what He wills. Surely He is Most Sublime, Most Wise" (42:51); and "Likewise, We have revealed to you a spirit by Our command, when before you did not know what the Book was, nor what faith was" (42:52).

However, one can benefit from these means only if his/her mind is enlightened and capable of digesting and then developing from this information the necessary theories and conclusions which will allow him/her to conduct his/her life in an Islamic manner. Apparently, it is not unusual for the mind to gain no benefit from the information which the senses provide, for Allah has said in the Qur'an: "And they must indeed have passed the town on which was rained a shower of evil; did they not see it?" (25:40); "Deaf, dumb and blind, they are void of wisdom" (2:171); and "Many are the jinn and men We have made for Hell. They have hearts that do not understand, eyes that do not see, and ears that do not hear. They are like cattle-nay, even more 
misguided. Indeed, such people, they are the heedless ones" (7:179).

We notice that there is not a third source of knowledge: taqlid (i.e., it is not an alternative to either revelation or science). Thus its use is unacceptable even if, in a rare instance, it does lead to what is right or correct. Instead, individuals are asked to discover the truth through the faculties which Allah has given them in order to explore, observe, and contemplate His creation. Allah has taught humanity to seek proof and to search for evidence. In order to emphasize this and to inform humanity that it should not give up this quest, even in matters having to do with Him, He has said: “. . . so that mankind, after the coming of the prophets, should have no proof against Allah" (4:165). It is as if Allah wanted to explain to humanity that it must make every effort to find the necessary evidence to support its position(s). Thus if Allah expects this sort of verification from humanity in its dealings with Him, what of its dealings on an individual level?

\section{How Did Muslims Sink to the Level of Taqlid?}

The ummah did not suddenly plunge to the depths of taqlid. On the contrary, we can locate the beginning of its gradual fall to the age of the Tàbi 'ün and as taking place in three phases: a) a gradual strengthening of the tendency to rely upon the opinions of the learned scholars; b) a de-emphasis among the people on learning and scholarly pursuits; and c) a general hardening of hearts throughout the ummah.

The major factor which initiated the first phase was the lack of interest on the part of individual Muslims to acquire true learning and hard evidence. Instead, there was a growing tendency to rely on the reputations of various scholars in the belief that such trust could replace his/her duty to seek evidence and proof for what the scholar taught.

Of course, it is true that the qurrā' and the fuqahä' with which the early generations of the Muslims were blessed were greatly respected for their learning and their piety, and deservedly so. However, the average Muslim soon forgot how these people used to ask the Prophet if he had spoken on the authority of his own opinion (which they could dispute) or of revelation (which would immediately end all controversy). Quite often, if the Prophet was relating his own opinion, he would encourage his Companions to help him make the correct decision. Sometimes he would even do what they suggested. There are many instances reported in which he said: "Come on, people! Tell me what to do." A similar case is found in his saying to "Umar and "Āmir: "Use ijtihad!" ${ }^{2}$ Indeed, this encouragement was what motivated

${ }^{12} \mathrm{~A}$ discussion of this particular hadith will follow in a forthcoming issue of AJISS. 
the ușūlì scholars to debate whether the Prophet's ijtihad was subject to error or not, for he taught them never to accept anything he said or did until they were certain that it was based on revelation. It was impossible for taqlid to exist among the Muslims in such an environment. As a matter of fact, taqlid was considered by the Muslims of this time to be one of the traits of the hypocrites and non-Muslims.

This state prevailed essentially from the hijrah until around the last Sahăbah's death in 99 AH. After this, deviation began to creep in as some Muslims seeking fatāwä began to feel somewhat awed in the presence of the great ulama and mujtahidūn like 'Umar ibn 'Abd al 'Azīz (101 AH), al Hasan al Bașrī (110 AH), and Ibn Sïrīn (110 AH). Their vast knowledge, when joined with the gap between the generation of the Sahäbah and that of the Täbi'ün, gradually caused them to seem somewhat larger than life to their contemporaries and instilled within the common people a certain reluctance, born of admiration, esteem, and perhaps not a little awe, to further ask those scholars for evidence corroborating their legal rulings and opinions. At this stage, however, the majority of questioners still demanded proof from the scholars, a practice which the latter knew was their duty to provide and therefore did not resent.

By the time of the third generation, however, learning and scholarly pursuits were no longer priorities with most Muslims, as they were more occupied with making a living. Thus very few had the time to attend the scholars' sessions in order to discuss knowledge or to study and reflect on the textual evidence presented. Instead, when they had questions they would satisfy themselves with an answer (minus the requisite proof) from the scholars. This new practice permeated the intellectual environment and lay the groundwork for the establishment of taqlid.

The third stage was characterized by the Muslim masses accustoming themselves to accepting legal opinions without listening to either arguments or evidence and by the legal scholars becoming comfortable with making pronouncements without justifying their reasons for doing so. It was in such an atmosphere that the following questions began to be asked: Is taqlid permissible for an individual who is not a scholar of the Shariah? Who is a scholar? Who is required to seek evidence? Who is incapable of searching for evidence on his/her own? Such questions divided the scholars of this period (circa $128 \mathrm{AH}$ ).

One group of scholars maintained that a scholar still had to explain his evidence to the questioner and that it was the latter's duty, as stated in the Shariah, to demand this evidence. This group also claimed that it was harām for a scholar not to explain his proof, for doing so would seriously hinder the questioner's ability to make up his/her own mind. Another group of people, however, held that it was permissible for a nonscholar to follow a scholar: 
that taqlid was haläl. This opinion led to the widespread saying: "An 'ämmì has no madhhab of his own; his madhhab is the madhhab of his mufit."

Thus, taqlid was given a certain amount of legitimacy, even though the ulama agreed in theory that it was blameworthy and prohibited. Despite this view, however, the popularity of taqlid continued to spread, a development which was to have very serious consequences for the Muslims' psychological disposition and mentality. It was at this point that taqlid began to create a serious gap in the Muslim mind, for its acceptance has led to generations of Muslims relying on unsubstantiated opinions and has resulted in the creation of a mentality and a proclivity for slavish imitation.

\section{Some of the Consequences of Taqlid}

Realizing that the ummah needed to change course, various people have searched for a cure. Among those suggested were a) codifying a certain madhhab, giving it government support, and then requiring all citizens to follow it and b) supporting only those madhähib followed by a significant number of Muslims.

Several factors led the ulama to such ideas. One of them was the split between the ummah's intellectual and political leadership which accompanied the deepening crisis of thought. Those in charge of the Muslims' affairs ( $\bar{u} l \bar{u}$ al amr) were divided into two mutually opposed parties: the rulers (who had the power) and the ulama (who had the legal proofs and arguments) ${ }^{13}$ The result of this polarization was that the former complementarity between these two groups was shattered and replaced by a ruinous conflict over legitimacy and earning the ummah's allegiance and support.

It was under such circumstances that the rulers began to think of codifying the legal texts and declaring a state madhhab. The 'Abbasid khalifah al Manșūr (d. 158 AH/755 AC) considered forcing his subjects to follow Imām Mālik's Muwațta'. Fearing that people would no longer deal directly with the Qur'an and the Sunnah if this policy were implemented, Mālik discouraged

${ }^{13}$ In his commentary on the Qur'an, al Manār (IV, 203-4), Rashīd Riḍa wrote: "It is well-known that the mufassirün give two interpretations to the term $\bar{u} l \bar{u}$ al amr: one is that they are the rulers or governmental authorities, and the second is that they are the scholars, in particular the fuqahä, or the legal authorities. It is equally well-known that there were no governmental authorities in the time of the Prophet and no group of people called fuqahä'. So the intended meaning of $\bar{u} l \bar{u}$ al $a m r$, as in the verse: 'When an issue of public security or agitation comes to them, they spread it abroad. But if they would refer it to the Prophet or to the authorities among them, those who derive meaning from it would come to know of it' (4:83), is the people of wisdom and importance in the ummah who have the ummah's interests at heart, who are capable of protecting those interests, and whose opinions are widely accepted by the ummah at large." 
this idea. Another reason for his doing so was that he realized that it might not be possible for one ruling given for a specific situation in one location to adequately solve a similar situation in another location.

Several attempts were made by various rulers to lend state support to one legal school or another, but in each case the scholars themselves opposed the idea because they feared that it might lead to taqlid.

Another factor which led to the increasing influence of taqlid was the growing belief in fatalism (jabr). This attitude helped taqlid gain even more adherents, and it became increasingly common for political leaders to seek justification for their mistakes and aberrations by citing this doctrine. Quite simply, if their actions and decisions had been determined for them beforehand, they could not be held accountable for them and their subjects could have no justification for rising in revolt against them. In effect, it gave them a carte blanche to rule the ummah as they saw fit. As it was to their advantage, many rulers and court-supported scholars favored it despite the opposition of the traditional ulama.

Taqlid thus cleared the way for fatalism, which in turn prepared the ground for tyranny, injustice, and despotism. The "great ones," to use the Qur'anic expression, accustomed themselves to giving orders, and the "lowly ones," by the same logic, learned to submit themselves. This result, which should clarify for the ummah once and for all the vital and inseparable relationship between taqlid and despotism, is even mentioned in the Qur'an: "Thus did he (Fir'awn) make fools of his people, and they obeyed him" (43:54) and "Fir'awn said: 'I but show you that which I see myself, nor do I guide you but to the path of right"' $(40: 29)$.

In conclusion, both the Qur'an and history show us that those who engage in taqlid soon lose sight of the truth of what they are following and do not think of the consequences. Through this voluntary cessation of independent thought, such people in effect hand over their destiny to whoever is able to establish control over them, even if this new leader leads them and the entire ummah to destruction.

Among the most obvious consequences of taqlid are the following:

First: The spread of indifference and the will to follow. Taqlid has created within the Muslim's psychological makeup feelings of his/her inability to accept responsibility. As the Shariah's essence is the acceptance of personal and communal responsibility, we may understand the extent of taqlid's negative effect upon the ummah.

Second: Taqlid and partisanship for a specific legal school have led to the 
spread of public debates on theological and legal topics which, in turn, have led to further polarization and increasing disunity among Muslims. The end result of such negative developments has been the emergence of popular factions and heretical sects dedicated to the destruction of Islam and the ummah. An even more dangerous result was that this taqlid-based mentality and fiqhbased partisanship gradually replaced the mentality of free inquiry which the Qur'an had instilled in the early Muslims.

Third: This taqlid-based mentality has also manifested itself among the previous generations of Muslims in their uncertainty regarding any legal decision for which there was no clear ruling. This mentality has filled present-day Muslims with misgivings about how to conduct themselves in different spheres of Islamic activity in the absence of an opinion from the classical scholars. Amazingly enough, the most important thing today is that the opinion cited be an old one; the writer's reputation or the work's value does not matter.

Contemporary Muslims who have grown up in such an intellectual void can hardly be expected to engage in any serious analysis of Islamic subjects whether they agree with the content or not. Instead, the ummah has defaulted on this duty and has left it to the orientalists, despite the latter's obvious biases and preferences, and to their clones among the Muslim students.

All of this has contributed to the creation of a very significant lacunae in our thought, which I call the vacuum of ijtihad. Out of fear of making an error, it seems that Muslims have declared this territory out of bounds for themselves, in effect leaving it to either non-Muslims or Westernized/secularized Muslims who no longer understand or practice the fundamental tenets of Islam. In short, it is wide open to the depredations of well-meaning but unqualified people as well as those who are hostile to Islam.

Fourth: The negative environment engendered by taqlid led to the creation of a consumptive syndrome, for Muslims began to retreat to their historical intellectual legacy in order to consume all that it had to offer. When the European awakening began, Muslims looked in all directions for a path to the position which they felt they deserved. However, when the keepers of the legacy were unable to provide direction, several groups within the ummah turned to the West. Their imitation of the West was based on the belief that such a step would meet with success. However, this was not to be, for they met instead with an identity crisis of such proportions that committed Muslims set out to find their historical identity while Westernized Muslims searched for a geographical or cultural identity. Such a development was only possible after taqlid had caused the ummah's personality to melt away by laying the foundations for its backwardness and introducing into it a state of civilizational absence despite its former civilizational preeminence.

Fifth: The ummah's taqlid-based mentality resulted in a worldview dominated 
by expedience. This, in turn, actually made taqlid a method for avoiding innovation (bidiah). As it was generally felt that ijtihad would lead to error or to one's adherence to the unacceptable, taqlid became attractive as a prudent alternative.

Sixth: Among taqlid's more disastrous side effects is its quasi-sanctification of the status quo, regardless of whether or not it adheres to the Shari'ah. As taqlid is the consort of custom, when the muqallidūn become more accustomed to certain social conditions they tend to block any movement for change or reform. Thus taqlid is an impediment to social reform and represents a mentality which must be either significantly altered or destroyed before meaningful change in a Muslim society can take place.

\section{Conclusion}

The curse of taqlid continues to obstruct the ummah's attempts at selfrevival and self-reform. Taqlid's negative and crippling effects cannot be overcome by changing the methods by which it is practiced or the people which it venerates. Nor can we expect to accomplish anything by transforming issues of taqlid into institutions which make a virtue of abandoning creative thought for the principle of following others and of designating certain people within the ummah as custodians of backwardness in the sacred name of taqlid.

\section{Symposium on the History of Medieval Islamic \& Occidental Mathematics}

The University of Oklahoma will host a symposium on the history of medieval Islamic \& Occidental mathematics on March 6-7, 1992. Entitled Tradition, Transmission, and Transformation: Ancient Mathematic in Its Islamic and Occidental Context, it will include the following participants: J.L. Berggren (Simon Fraser University); Sonja Brentjes (Karl Marx Universitaat, Leipzig); Menso Folkerts (Universitaat Munchen); Jan P. Hogendijk (Rijksuniversiteit te Utrecht); A.G. Molland (University of Aberdeen); and Warren Van Egmond (Arizona State University).

For information, contact

Professor Steven J. Livesey

Dept. of the History of Science

University of Oklahoma

Phone: 405-325-2213

601 Elm, Room 622

Fax: 405-325-5968

Norman, OK 73019

E-mail: Bitnet AA9214@UOKMVSA 